\title{
ANALISIS KUALITAS SIRUP JERUK BABY JAVA PADA STASIUN PROSES DAN PENDUGAAN UMUR SIMPAN SKALA PILOT PLANT
}

\author{
Quality Analysis and Shelf Life Assessment of Baby Java Citrus Fruit Syrup \\ at Each Process in Pilot Plant Scale
}

\author{
Randy Yulidar Anggara Puri, Susinggih Wijana, Dodyk Pranowo \\ Jurusan Teknologi Industri Pertanian - Fakultas Teknologi Pertanian - Universitas Brawijaya \\ Jl. Veteran Malang 65145 \\ *Penulis Korespondensi: email: randyyulidar@gmail.com
}

\begin{abstract}
ABSTRAK
Buah jeruk merupakan salah satu buah yang berpotensi tinggi di Indonesia dengan hasil produksi menduduki peringkat ke-10 dunia. Varietas yang cukup banyak dibudidayakan yaitu jeruk manis baby java (Citrus sinensis). Jeruk diproduksi menjadi sirup dengan memperhatikan beberapa aspek, yaitu efektivitas proses terhadap penurunan kontaminasi mikroba dan masa simpan produk. Pengujian efektivitas proses dilakukan dengan mendeteksi kandungan mikroorganisme bahan setelah melewati tiap stasiun proses. Masa simpan produk diuji dengan metode Accelerated Shelf Life Time (ASLT) yang dioptimalkan dengan persamaan Arrhenius. Metode ini menggunakan faktor suhu penyimpanan sebagai penentu kecepatan reaksi kerusakan bahan. Adapun suhu penyimpanan yaitu $35^{\circ} \mathrm{C}, 40{ }^{\circ} \mathrm{C}$, dan $45^{\circ} \mathrm{C}$ dengan parameter yang diamati yaitu total mikroba, kadar vitamin $\mathrm{C}$, total padatan terlarut, dan $\mathrm{pH}$. Hasil penelitian didapatkan bahwa proses produksi dapat secara signifikan menurunkan kandungan mikroba pada bahan dengan kandungan mikroba pada stasiun proses pertama dan akhir masing-masing sebesar 9.87 $x 10^{2} \mathrm{CFU} / \mathrm{ml}$ dan $0 \mathrm{CFU} / \mathrm{ml}$. Pendugaan masa simpan didapatkan $\mathrm{pH}$ memiliki energi aktivasi (EA) terendah sebesar 467.46 dengan pendugaan apabila sirup jeruk disimpan pada suhu $7{ }^{\circ} \mathrm{C}$ dapat bertahan hingga 42 hari.
\end{abstract}

Kata kunci : Arrhenius, ASLT, Energi Aktivasi, TPC

\begin{abstract}
Oranges have high potential in Indonesia with $10^{\text {th }}$ production in the world. The most varieties cultived was sweet orange baby java (Citrus sinensis). Citrus was produced to syrup by considering several aspects, process effectiveness to decrease microbial contamination and shelf life of the product. Process effectiveness assessment was determined by detecting the content of microorganisms in material after each process station. Product shelf life assessment was tested by using Accelerated Shelf Life Time (ASLT) method using Arrhenius equation. This method use factor of storage temperature as a determinant speed reaction of material defect. Product was stored in several temperature, $35^{\circ} \mathrm{C}, 40^{\circ} \mathrm{C}$, and $45^{\circ} \mathrm{C}$. Parameters observed were total microbes, vitamin $\mathrm{C}$ contents, total dissolved solids, and $\mathrm{pH}$. The results showed that the production process could significantly reduce microbial content in material, at first and final process stations were $9.87 \times 10^{2} \mathrm{CFU} / \mathrm{ml}$ and $0 \mathrm{CFU} / \mathrm{ml}$, respectively. The assessment of shelf life was obtained that $p H$ had the lowest activation energy (EA) is 467.46. The prediction of shelf life showed that the orange syrup can be stored for 42 days at $7^{\circ} \mathrm{C}$.
\end{abstract}

Keywords : Activation Energy, Arrhenius, ASLT, TPC 


\section{PENDAHULUAN}

Produksi buah jeruk (Citrus sp.) di Indonesia cukup besar yaitu tahun 2014 sebesar 2243837 ton dengan luas lahan mencapai 43.170 ha. Produksi tersebut mengalami peningkatan produksi dari tahun 2010 hingga 2014 dengan rata-rata kenaikan sebesar $4.13 \%$ /tahun. Adapun salah satu sentra budidaya jeruk yaitu desar Selorejo, kecamatan Dau, kabupaten Malang. Varietas yang banyak dikembangkan yaitu jeruk manis baby java (Citrus sinensis L.) dengan luas budidaya mencapai \pm 400 ha dengan total produksi mencapai 12000 ton/tahun (Zakaria et al., 2013).

Pengolahan sirup diharapkan dapat meningkatkan nilai ekonomi dan menambah masa simpan jeruk baby java. Menurut Margono et al. (2000) sirup buah atau sari buah pekat merupakan cairan yang dihasilkan dari proses pengepresan daging buah dan dilanjutkan dengan pemekatan, baik secara pendidihan biasa atau dengan cara lain seperti penguapan hampa udara. Berdasarkan bahan baku utama sirup dibedakan menjadi tiga, yaitu sirup essence yang cita rasanya ditentukan oleh essence yang ditambahkan. Sirup glukosa hanya mempunyai rasa yang manis saja, sering juga disebut gula encer. Sirup ini biasanya tidak langsung dikonsumsi tapi merupakan bahan baku industri minuman sari buah. Sirup buah adalah jenis yang ketiga, yaitu sirup yang cita rasanya ditentukan oleh bahan dasarnya yaitu buah segar seperti jambu, markisa, nanas, mangga dan lain-lain (Satuhu, 2004; Jafarpour et al., 2016).

Sebagian besar kandungan sirup adalah air sehingga rentan terhadap pertumbuhan mikroorganisme (Rienoviar dan Nashrianto, 2010). Adapun batas maksimum cemaran mikroba pada produk akhir sirup yaitu dinyatakan dalam angka lempeng total (ALT $/ 30^{\circ} \mathrm{C}, 72 \mathrm{jam}$ ) sebesar $5 \times 10^{2}$ koloni/ $\mathrm{ml}$ (BPOM, 2016). Deteksi cemaran mikroba dilakukan pada tiap stasiun proses skala pilot plant. Pilot plant merupakan langkah yang dirancang untuk menguji proses dan kebutuhan produksi dalam simulasi skala kecil. Tujuan langkah ini menghasilkan informasi yang cukup untuk menentukan apakah proyek dapat dikembangkan ke skala komersial. Prinsip teknik skala pilot plant adalah perbesaran dari skala laboratorium ke skala yang lebih besar dengan penilaian efisiensi yang lebih terperinci, sehingga diperoleh teknologi yang menghasilkan produk yang layak secara ekonomis (Palluzi, 2009; Andrzejewski et al., 2013; da Silva et al., 2017; Kwan et al., 2018).

Menurut Pato et al. (2012) keterangan masa simpan wajib diberikan pada label kemasan oleh produsen. Jangka waktu akumulasi hasil reaksi yang mengakibatkan mutu produk makanan tidak lagi dapat diterima disebut sebagai jangka waktu kadaluarsa (Syarif dan Halid, 1993). Ketika produk dalam kondisi yang tidak dapat dikonsumsi dapat dikatakan bahwa produk telah mencapai akhir masa simpan (McCurdy et al., 2009). Salah satu metode penentuan masa simpan produk yaitu Accelerated Shelf-Life Time (ASLT) yang menggunakan beberapa parameter kondisi penyimpanan yang dapat mempercepat reaksi penurunan mutu daripada kondisi normal (Steele, 2004; Kebede et al., 2015; Upasen dan Wattanachai, 2018). Adapun faktor yang diamati yaitu suhu penyimpanan, dimana kenaikan suhu berpengaruh terhadap kecepatan reaksi kerusakan bahan pangan (Robertson, 1993).

Oleh karena itu, penelitian ini dilakukan untuk mendeteksi cemaran mikroorganisme setelah bahan melewati berbagai stasiun proses. Selain itu dilakukan pendugaan masa simpan sirup jeruk dengan metode ASLT dan dioptimalkan dengan persamaan Arrhenius.

\section{BAHAN DAN METODE}

\section{Bahan}

Bahan baku yang digunakan yaitu jeruk baby java grade C (subgrade) diperoleh dari desa Selorejo, kecamatan Dau, kabupaten Malang. Bahan tambahan yang digunakan antara lain fruktosa, gula KA, asam sitrat, dan CMC, masing-masing diperoleh dari PT Raya Sugarindo Inti dan toko kimia. Bahan untuk analisa kualitas kimia yaitu aquades, amilum $1 \%$, dan iodin $0.01 \mathrm{~N}$. Bahan untuk analisa mikrobiologi yaitu aquades, alkohol 96\%, dan media PCA (Plate Count Agar-OXOID).

\footnotetext{
Alat

Peralatan untuk pembuatan sirup jeruk baby java skala ganda yaitu mesin pembuat minuman multifungsi kapasitas 80 l, mesin PEF (Pulse Electric Field), termometer, takaran air, timbangan (Deluxe), kompor gas, pengaduk kayu, pisau, kain saring, dan
} 
alat pemeras (orange juicer with handle). Alat untuk analisa yaitu timbangan analitik, pipet tetes, water bath, spektrofotometer, refraktometer (Atago), piknometer, $\mathrm{pH}$ meter (Trans), dan viskometer. Alat analisa total mikroba adalah cawan petri, kompor listrik, kapas, kasa, bunsen, tabung reaksi, kertas coklat, plastik, gunting, blue tip, mikropipet, laminar air flow, dan inkubator (Bionex) dengan suhu $30^{\circ} \mathrm{C}$. Alat yang digunakan untuk pendugaan masa simpan adalah inkubator dengan suhu $35^{\circ} \mathrm{C}, 40^{\circ} \mathrm{C}$, dan $45^{\circ} \mathrm{C}$.

\section{Metode}

\section{Produksi Sirup Jeruk Skala Pilot Plant}

Proses produksi sirup pada penelitian ini mengacu pada penelitian sebelumnya bahwa campuran asam sitrat sebanyak $2 \%$; CMC 1\%; fruktosa:sari jeruk = 1:1; dan air 11/ $\mathrm{kg}$. Keseluruhan bahan dicampur pada reaktor berpengaduk dan dimasak serta dijaga total padatan terlarut minimal $50^{\circ} \mathrm{Brix}$. Hal ini untuk menjaga mutu sirup (Dewi, 2016). Selanjutnya sirup dikemas dalam botol kaca.

\section{Pengujian Mutu Sirup Jeruk}

Analisis Vitamin C (Marta et al., 2008)

Sebanyak $10 \mathrm{~g}$ bahan dimasukkan ke labu ukur $100 \mathrm{ml}$, kemudian ditambahkan asam oksalat $5 \%$ sampai batas, lalu dikocok dan disaring dengan kertas saring. Filtrat hasil penyaringan diambil sebanyak $10 \mathrm{ml}$ dan dimasukkan ke erlenmeyer 100 ml. Filtrat kemudian ditambah $2 \mathrm{ml}$ indikator amilum $1 \%$ dan aquades sebanyak $15 \mathrm{ml}$. Larutan dititrasi dengan larutan I2 $0.01 \mathrm{~N}$ sampai terbentuk larutan berwarna biru. Kadar vitamin $C$ dapat diketahui dengan perhitungan pada Persamaan 1.

$1 \mathrm{ml}$ larutan $\mathrm{I}_{2} 0.01 \mathrm{~N}=0.88 \mathrm{mg}$ vitamin $\mathrm{C} \ldots$

\section{Analisis Total Padatan Terlarut (Mukaromah et al., 2010)}

Uji total padatan terlarut (TPT) menggunakan hand refractometer, yaitu dengan meneteskan sampel sirup pada kaca sensor yang ada pada hand refractometer. Selanjutnya dilakukan pembacaan skala dengan melihat pada teropong refractometer. Total padatan terlarut dinyatakan dalam persen Brix (derajat Brix).

\section{Analisis pH (Nordstrom et al., 2000)}

Nilai $\mathrm{pH}$ sirup diukur dengan mengambil sedikit sediaan kemudian kertas $\mathrm{pH}$ dimasukkan ke dalam sirup tersebut setelah terjadi perubahan warna pada kertas kemudian dicocokkan dengan angka yang terdapat pada indikator $\mathrm{pH}$. Nilai $\mathrm{pH}$ berkisar dari 0-14. Suatu larutan dikatakan netral apabila memiliki nilai $\mathrm{pH} 7$. Nilai $\mathrm{pH}$ lebih dari 7 akan menunjukkan sifat basa dan nilai kurang dari 7 menunjukkan tingkat keasaman.

\section{Analisis Total Mikroba (BPOM, 2012)}

Perhitungan kandungan mikroba dilakukan dengan TPC (total plate count) yang dilakukan pada cawan petri. Sampel sirup jeruk diambil dari tiap stasiun proses sebanyak 125 $\mathrm{ml}$ dimasukkan ke botol kaca dan disimpan pada refrigerator hingga dilakukan pengujian. Adapun pengujian dilakukan dengan tahapan tiap sampel diambil $1 \mathrm{ml}$ dan diencerkan hingga $10^{-3}$ mengikuti metode pengenceran dan diuji kandungan mikroba dengan metode pour plate pada cawan petri kemudian diinkubasi pada suhu $30^{\circ} \mathrm{C}$ selama 72 jam.

\section{Penentuan Karakteristik Mutu Kritis Sirup} Sampel sirup dianalisa mutu awal $\left(\mathrm{A}_{0}\right)$ meliputi kadar vitamin C (\%), pH, TPT, dan TPC, kemudian disimpan suhu tertinggi, yaitu $45{ }^{\circ} \mathrm{C}$. Pengamatan dilakukan melalui uji kuesioner secara organoleptik dengan metode hedonic scale scoring (Lawless dan Heymann, 1998) setiap 5 hari sekali hingga sampel ditolak panelis lebih dari 50\%. Saat sampel telah ditolak, pengamatan dihentikan dan sampel dianalisa sebagai mutu akhir $\left(A_{t}\right)$. Panelis yang dipilih yaitu panelis ahli dalam bidang olahan sari buah khususnya jeruk sebanyak 5 panelis.

\section{Pendugaan Umur Simpan Sirup Jeruk}

Sampel sirup disimpan pada inkubator dan diamati mengikuti plot pada Tabel 1. Parameter yang diamati yaitu TPC, kadar vitamin $\mathrm{C}$, pH, dan TPT. Data hasil analisa diplotkan terhadap waktu dan dicari persamaan regresi linier, yaitu $y=a+b x$, dimana $y$ adalah nilai karakterisitik sirup, $x$ adalah waktu penyimpanan, $a$ adalah nilai karakteristik sirup, dan $b$ adalah laju perubahan karakteristik.

Ordo reaksi yang digunakan yaitu ordo dengan nilai $\mathrm{R}^{2}$ lebih besar (Labuza dan Riboh, 2007). Nilai $b$ merupakan konstanta laju reaksi (k) digunakan untuk tahap selanjutnya. Nilai ln $k$ diplotkan dengan $1 / \mathrm{T}$ dan dicari persamaan regresi linier $\ln k=\ln$ $k_{0}-\left(E_{A} / R\right)(1 / \mathrm{T})$, dimana $\ln k_{0}=$ intersep,$E_{A} / R$ = slope, $\mathrm{E}_{\mathrm{A}}=$ energi aktivasi, dan $\mathrm{R}=$ konstanta gas ideal $\left(1.986 \mathrm{kal} / \mathrm{mol}^{\circ} \mathrm{K}\right)$. 
Selanjutnya dapat ditentukan model persamaan laju reaksi $(\mathrm{k})$ dengan persamaan Arrhenius $k=k_{0} \cdot e^{-E A / R}$, kemudian dipilih parameter dengan nilai $\mathrm{E}_{\mathrm{A}}$ terendah. Hal ini dikarenakan semakin rendah nilai $\mathrm{E}_{\mathrm{A}^{\prime}}$ suatu reaksi akan berjalan lebih cepat sehingga semakin cepat berkontribusi terhadap kerusakan produk (Widya dan Yuwono, 2014). Masa simpan dihitung dengan persamaan kinetika reaksi berdasarkan ordo parameter yaitu $A t=A_{0}-k t$, dimana $\mathrm{A}_{0}$ adalah konstanta A pada $\mathrm{t}=0$, At adalah konstanta A pada $t$ akhir.

\section{HASIL DAN PEMBAHASAN}

\section{Teknologi Proses Skala Pilot Plant}

Secara keseluruhan, proses produksi dibagi dalam empat kelompok stasiun proses, yaitu stasiun preparasi (pencucian), stasiun ekstraksi (pemotongan, pemerasan, dan penyaringan), stasiun pemasakan (pemanasan, kejut listrik, dan pendinginan), dan stasiun pembotolan. Peralatan yang digunakan harus aman untuk digunakan karena menyangkut keamanan produk. Menurut Triharjono et al. (2013) prosedur untuk menjaga area perusahaan dan fasilitas produksi perlu dilakukan untuk mencegah terjadinya penyakit dengan menghilangkan atau minimal mengatur faktor lingkungan berkaitan dengan perpindahan penyakit.

Tahap pertama jeruk disortasi untuk mendapatkan kualitas yang baik berdasarkan kenampakan luar yaitu tidak busuk, tidak mengeluarkan air dan bau, serta tidak pecah. Buah hasil sortasi dicuci dengan air bersih dan sabun. Buah hasil pencucian masuk ke stasiun ekstraksi yang dimulai dengan pemotongan secara horizontal menjadi dua bagian yang sama besar untuk memudahkan proses pemerasan. Potongan buah selanjutnya diperas untuk mendapatkan sari buah yang akan disaring untuk memisahkan pulp dari sari buah. Hasil penyaringan kemudian melewati proses pemanasan disertai pemberian kejut listrik (PEF) dan pencampuran bahan tambahan (CMC, asam sitrat, fruktosa) pada mesin pembuat minuman multifungsi. Penggunaan suhu yang tidak terlalu tinggi disertai PEF yaitu mempertahankan atribut kualitas sirup (Kumar et al., 2015). Tahap terakhir yaitu pembotolan sirup hasil proses dengan memberikan sedikit ruang pada botol (headspace) agar tekanan bahan terhadap wadah tidak terlalu tinggi yang dapat menyebabkan kerusakan botol (Fish, 2012).

\section{Karakteristik Mutu Sirup Jeruk}

Hasil proses didapatkan kandungan proksimat sirup (Tabel 2). Selanjutnya ditentukan nilai mutu kritis pada awal penyimpanan $\left(A_{0}\right)$ dan akhir penyimpanan $\left(A_{t}\right)$ (Tabel 3). Nilai mutu kritis digunakan pada pendugaan masa simpan.

Hasil pengujian kuesioner didapatkan bahwa nilai parameter organoleptik selama penyimpanan terus mengalami penurunan. Sampel ditolak oleh lebih dari $50 \%$ panelis pada pengamatan hari ke-35, yaitu ditolak oleh $60 \%$ panelis atau 3 orang. Parameter rasa mengalami penurunan lebih signifikan dibandingkan parameter warna dan aroma. Oleh karena itu dapat disimpulkan bahwa parameter rasa pada pengujian organoleptik merupakan kriteria penentu penolakan konsumen terhadap sirup jeruk.

Pengamatan pada hari ke-35 dihentikan. Panelis sebanyak lebih dari 50\% menolak sampel (Tabel 3). Selanjutnya dilakukan analisa mutu sirup dengan parameter yang diamati yaitu total mikroorganisme, kadar vitamin $\mathrm{C}$, total padatan terlarut, dan $\mathrm{pH}$.

\section{Efektivitas Proses Produksi Sirup Jeruk}

Pengujian efektivitas proses produksi dilakukan dengan pendeteksian kandungan mikroba pada tiap stasiun proses, yaitu mulai persiapan bahan baku hingga pengemasan. Hasil analisis menunjukkan bahwa proses produksi dapat menurunkan kandungan mikroorganisme pada produk sirup, dimana kandungan mikroba pada bahan baku diketahui sangat tinggi, yaitu $9.87 \times 10^{2}$ $\mathrm{CFU} / \mathrm{ml}$, kemudian pada akhir proses tidak didapatkan total mikroba (Gambar 1).

Stasiun proses yang terdeteksi adanya total mikroba diduga dari cemaran mikroba sebelum proses ataupun saat proses berlangsung. Total mikroba tertinggi terdapat pada stasiun proses pertama, yaitu persiapan bahan baku sebesar $9.87 \times 10^{2} \mathrm{CFU} / \mathrm{ml}$. Mikroba diduga banyak terdapat pada kulit buah sehingga saat dilakukan pendeteksian cemaran mikroba, sebagian mikroba akan mengkontaminasi hasil pengujian. Menurut Olorunjuwon $\mathrm{O}$ et al. (2014) jenis-jenis mikroorganisme yang dimungkinkan dapat mencemari sari jeruk diantaranya E. coli, S. aureus, Serratia sp., 
Proteus spp., Saccharomyces cerevisiae, Mucor spp., dan Aspergillus niger. Proses kedua yaitu stasiun proses pencucian dan pemotongan tidak ditemukan adanya total mikroba. Hal ini diduga pencucian dengan sabun dapat secara signifikan mengurangi kontaminasi mikroba.

Stasiun proses ketiga yaitu penyaringan sari jeruk ditemukan adanya kandungan mikroba sebesar $4.00 \times 10^{1} \mathrm{CFU} / \mathrm{ml}$. Kontaminasi mikroba diduga disebabkan adanya cemaran mikroba pada peralatan yang digunakan. Walaupun peralatan yang digunakan telah dibersihkan, akan tetapi tetap kontak dengan udara, sehingga apabila mikroba yang ada di udara menempel pada peralatan, maka akan mencemari sari jeruk. Total mikroba terus mengalami kenaikan pada stasiun proses keempat, pencampuran bahan, sebesar $9.00 \times 10^{1} \mathrm{CFU} / \mathrm{ml}$. Diduga populasi mikroba dari stasiun proses penyaringan terus mengalami kenaikan hingga stasiun proses pencampuran bahan.

Berdasarkan Gambar 1, kandungan mikroba mengalami penurunan kembali pada tahap proses kelima, yaitu pemanasan serta pemberian kejut listrik (PEF). Hal ini diduga teknologi PEF dapat membunuh dan menginaktivasi mikroba (Ramaswamy dan Marcotte, 2005). Cemaran mikroba pada stasiun pengemasan tidak ditemukan adanya kontaminasi mikroba. Hal ini sesuai dengan prosedur pengemasan yang menghilangkan adanya cemaran mikroba pada produk akhir.

\section{Kinetika Reaksi Pendugaan Masa Simpan Perubahan Total Mikroba}

Pengujian total mikroba melalui metode total plate count (TPC) dengan kondisi suhu penyimpanan yang berbeda yaitu pada suhu $35^{\circ} \mathrm{C}, 40^{\circ} \mathrm{C}$, dan $45^{\circ} \mathrm{C}$, kemudian nilai parameter diplotkan terhadap masa penyimpanan (Gambar 2a). Berdasarkan Gambar 2, dapat diketahui bahwa semakin lama penyimpanan maka total jumlah mikroba pada sirup jeruk semakin tinggi. Selanjutnya, dicari persamaan regresi linier antara perubahan total mikroba dan waktu penyimpanan, sesuai dengan Persamaan 2, 3, dan 4.

Suhu $35^{\circ} \mathrm{C}\left(308^{\circ} \mathrm{K}\right): y=0.2464 x-0.9404 \ldots(2)$ Suhu $40^{\circ} \mathrm{C}\left(313^{\circ} \mathrm{K}\right): y=0.2338 x-0.8966 \ldots$ (3) Suhu $45^{\circ} \mathrm{C}\left(318^{\circ} \mathrm{K}\right): y=0.2227 x-0.9269 \ldots(4)$

Pada Persamaan 2, 3, 4, regresi linier tersebut akan menghasilkan nilai $\mathrm{k} / \mathrm{b} /$ slope yang merupakan laju reaksi peningkatan total mikroba pada setiap suhu penyimpanan sirup jeruk. Nilai $k$ untuk peningkatan total mikroba tertinggi terjadi pada suhu $35{ }^{\circ} \mathrm{C}$ yaitu 0.2464 . Nilai $k$ semakin kecil seiring dengan suhu penyimpanan yang semakin tinggi. Hal ini diperkuat oleh pendapat Syarif dan Halid (1993) bahwa suhu merupakan faktor yang berpengaruh terhadap mutu pangan. Laju reaksi yang semakin cepat menyebabkan kerusakan produk sehingga masa simpan semakin pendek. Berdasarkan Gambar 2a dapat diketahui bahwa kandungan mikroba pada suhu $35^{\circ} \mathrm{C}$ cenderung lebih tinggi daripada suhu penyimpanan $40^{\circ} \mathrm{C}$ dan $45^{\circ} \mathrm{C}$. Hal tersebut diduga pada suhu 35 ${ }^{\circ} \mathrm{C}$ mikroba khususnya kapang dan khamir tumbuh lebih tinggi dibandingkan suhu penyimpanan lainnya. Beberapa kapang dapat tumbuh pada suhu $35{ }^{\circ} \mathrm{C}$ (Muchtadi, 2010; Dagnas et al., 2014; Luethy dan Zelazny, 2018; Rico-Munoz et al., 2018). Tiga konstanta peningkatan total mikroba tersebut kemudian diterapkan pada persamaan Arrhenius, yaitu $\ln k=\ln \mathrm{k}_{0-}(E / R T)$. Setiap nilai $\ln k$ dan $1 / \mathrm{T}$ (satuan suhu dalam Kelvin) pada tiap suhu penyimpanan diplotkan sebagai ordinat dan absis. Parameter Arrhenius perubahan total mikroba pada sirup jeruk, yaitu 1/T dan $\ln$ $K$ dapat dilihat pada Tabel 5. Plot antara nilai $1 / \mathrm{T}$ dan $\ln k$ menghasilkan grafik hubungan penurunan total mikroba dan suhu penyimpanan dengan persamaan reaksi regresi linier $y=990.63 x-4.6175$ dan koefisien determinasi $\left(R^{2}\right)$ sebesar 0.9608 (Gambar 3a). Jika nilai $\mathrm{R}^{2}$ mendekati +1 atau $\mathrm{R}^{2}$ mendekati -1 maka Jika nilai $R^{2}=+1$ atau $R^{2}=-1$ maka $X$ dan $Y$ memiliki korelasi linier sempurna. Jika nilai $\mathrm{R}^{2}=0$ maka $X$ dan $Y$ tidak memiliki relasi (hubungan) linier (Park et al., 2013; Liu et al., 2015; Dahlquist-Willard et al., 2016). Koefisien determinasi mendekati satu $\left(\mathrm{R}^{2} \sim 1\right)$ artinya korelasi (hubungan) antara suhu dan penurunan total mikroba sebesar 0.9998 (sangat tinggi). Menurut Muchtadi (2010) suhu optimal bakteri mesofilik memperbanyak diri dengan cepat adalah $25{ }^{\circ} \mathrm{C}-30{ }^{\circ} \mathrm{C}$. Penyimpanan pada suhu ruangan (sesuai suhu lingkungan) akan menyebabkan penurunan mutu fisik, kimia dan organoleptik dan gizi sangat cepat yang diikuti proses pembusukan dibandingkan dengan suhu stabil.

\section{Perubahan Kadar Vitamin C}

Pengaruh penyimpanan terhadap kadar vitamin $C$ diketahui dengan membuat 
Jurnal Teknologi Pertanian Vol. 19 No. 2 [Agustus 2018] 125-138

Analisis Kualitas Sirup Jeruk Baby Java [Yulidar dkk]

Tabel 1. Plot pengamatan masa simpan

\begin{tabular}{ccccccccc}
\hline \multirow{2}{*}{ Suhu $\left({ }^{\circ} \mathrm{C}\right)$} & \multicolumn{8}{c}{ Hari Ke- } \\
\cline { 2 - 9 } & $\mathbf{0}$ & $\mathbf{5}$ & $\mathbf{1 0}$ & $\mathbf{1 5}$ & $\mathbf{2 0}$ & $\mathbf{2 5}$ & 30 & 35 \\
\hline 35 & $\bullet$ & $\bullet$ & $\bullet$ & $\bullet$ & $\bullet$ & $\bullet$ & $\bullet$ & $\bullet$ \\
40 & $\bullet$ & $\bullet$ & $\bullet$ & $\bullet$ & $\bullet$ & $\bullet$ & $\bullet$ & $\bullet$ \\
45 & $\bullet$ & $\bullet$ & $\bullet$ & $\bullet$ & $\bullet$ & $\bullet$ & $\bullet$ & $\bullet$ \\
\hline
\end{tabular}

Tabel 2. Hasil analisis proksimat sirup

\begin{tabular}{cc}
\hline Parameter & Kandungan \\
\hline Air (\%) & 89.43 \\
Vitamin C (mg) & 41.82 \\
Protein (\%) & 0.48 \\
Lemak (\%) & 0.14 \\
Abu (\%) & 0.27 \\
Karbohidrat (\%) & 9.68 \\
\hline
\end{tabular}

Tabel 3. Uji penerimaan panelis

\begin{tabular}{ccccc}
\hline \multirow{2}{*}{ Hari Ke- } & \multicolumn{3}{c}{ Parameter } & \multirow{2}{*}{ \% Menolak } \\
\cline { 2 - 4 } & Warna & Aroma & Rasa & 0.00 \\
\hline 0 & 12.60 & 12.20 & 12.80 & 0.00 \\
5 & 11.40 & 11.20 & 11.20 & 0.00 \\
10 & 10.60 & 10.20 & 10.40 & 20.00 \\
15 & 10.40 & 9.60 & 9.20 & 20.00 \\
20 & 9.60 & 9.00 & 8.40 & 40.00 \\
25 & 8.20 & 7.80 & 6.80 & 40.00 \\
30 & 6.60 & 5.80 & 4.80 & 60.00 \\
35 & 5.40 & 4.60 & 3.80 & \\
\hline
\end{tabular}

Tabel 4. Nilai mutu kritis sirup jeruk

\begin{tabular}{lcc}
\hline Parameter Mutu & $\mathbf{A}_{0}$ & $\mathbf{A}_{\mathbf{t}}$ \\
\hline TPC (CFU/ml) & 0 & $6.25 \times 10^{2}$ \\
Vitamin C (\%) & 0.63 & 0.11 \\
TPT ( ${ }^{\circ}$ Brix) & 41.05 & 47.10 \\
$\mathrm{pH}$ & 6.30 & 2.01 \\
\hline
\end{tabular}

Tabel 5. Persamaan arrhenius TPC

\begin{tabular}{cccc}
\hline Suhu $\left({ }^{\circ} \mathbf{K}\right)$ & $\mathbf{1} / \mathbf{T}$ & Slope $/ \mathbf{b} / \mathbf{k}$ & Ln $\mathbf{K}$ \\
\hline 308 & 0.00325 & 0.2464 & -1.40080 \\
313 & 0.00319 & 0.2338 & -1.45329 \\
318 & 0.00314 & 0.2227 & -1.50193 \\
\hline
\end{tabular}


Tabel 6. Persamaan arrhenius kadar vitamin C

\begin{tabular}{cccc}
\hline Suhu $\left({ }^{\circ} \mathbf{K}\right)$ & $\mathbf{1} / \mathbf{T}$ & Slope $/ \mathbf{b} / \mathbf{k}$ & Ln $\mathbf{k}$ \\
\hline 308 & 0.00325 & 0.0132 & -4.3275 \\
313 & 0.00319 & 0.0153 & -4.1799 \\
318 & 0.00314 & 0.0159 & -4.1414 \\
\hline
\end{tabular}

Tabel 7. Persamaan arrhenius TPT

\begin{tabular}{cccc}
\hline Suhu $\left({ }^{\circ} \mathbf{K}\right)$ & $\mathbf{1 / T}$ & Slope $/ \mathbf{b} / \mathbf{k}$ & Ln $\mathbf{k}$ \\
\hline 308 & 0.00325 & 0.1697 & -1.7737 \\
313 & 0.00319 & 0.1606 & -1.8288 \\
318 & 0.00314 & 0.1926 & -1.6471 \\
\hline
\end{tabular}

Tabel 8. Persamaan arrhenius $\mathrm{pH}$

\begin{tabular}{cccc}
\hline Suhu $\left({ }^{\circ} \mathbf{K}\right)$ & $\mathbf{1} / \mathbf{T}$ & Slope $/ \mathbf{b} / \mathbf{k}$ & Ln $\mathbf{k}$ \\
\hline 308 & 0.00325 & 0.0288 & -3.54738 \\
313 & 0.00319 & 0.0292 & -3.53359 \\
318 & 0.00315 & 0.0295 & -3.52337 \\
\hline
\end{tabular}

Tabel 9. Hasil perhitungan EA tiap parameter

\begin{tabular}{lc}
\hline Parameter Mutu & $\mathbf{E}_{\mathbf{A}}(\mathbf{k a l} / \mathbf{m o l})$ \\
\hline Angka Lempeng Total Mikroba & 1967.39 \\
Kadar Vitamin C (\%) & 3631.00 \\
Total Padatan Terlarut ( ${ }^{\circ}$ Brix) & 2437.62 \\
pH & 467.46 \\
\hline
\end{tabular}

Tabel 10. Pendugaan masa simpan sirup jeruk

\begin{tabular}{lccc}
\hline Persamaan & $\mathbf{t}\left({ }^{\circ} \mathbf{C}\right)$ & Nilai $\boldsymbol{k}$ & Masa Simpan (Hari) \\
\hline $\mathrm{y}=-235.38 \mathrm{x}-2.7826$ & 7 & 0.0267 & 42 \\
$\mathrm{y}=-235.38 \mathrm{x}-2.7826$ & 25 & 0.0281 & 40 \\
$\mathrm{y}=-235.38 \mathrm{x}-2.7826$ & 35 & 0.0288 & 39 \\
\hline
\end{tabular}

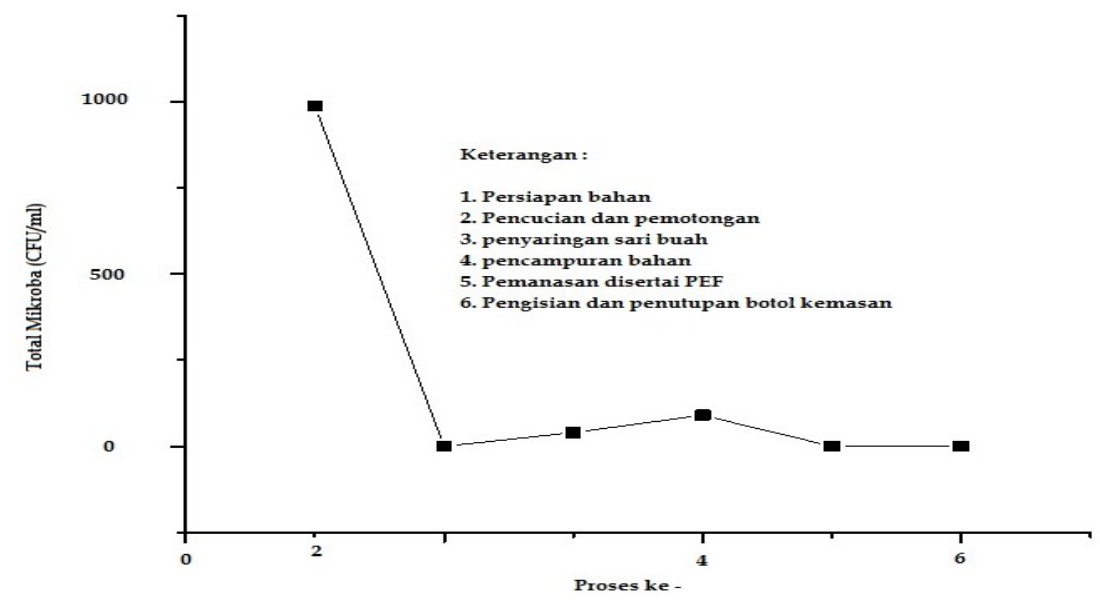

Gambar 1. Laju total mikroba tiap stasiun proses 
persamaan regresi linier disertai pemilihan orde reaksi. Orde reaksi yang digunakan untuk perubahan kadar vitamin $\mathrm{C}$ adalah orde nol dikarenakan nilai $\mathrm{R}^{2}$ ordo nol lebih besar dari nilai $\mathrm{R}^{2}$ orde satu. Plot data hasil per kadar vitamin $C$ selama penyimpanan pada suhu $35^{\circ} \mathrm{C}, 40^{\circ} \mathrm{C}$, dan $45^{\circ} \mathrm{C}$ dapat dilihat pada Gambar 2b. Masa penyimpanan diketahui menurunkan kadar vitamin $\mathrm{C}$ seiring dengan semakin lamanya waktu penyimpanan. Hal ini menunjukkan bahwa kadar vitamin $\mathrm{C}$ akan menurun seiring penyimpanan sirup sehingga dapat menurunkan mutu sirup jeruk. Berdasarkan hasil perhitungan dapat diketahui persamaan regresi linier antara kadar vitamin $C$ dengan waktu penyimpanan, sesuai dengan Persamaan 5, 6, 7 .

Suhu $35^{\circ} \mathrm{C}\left(308^{\circ} \mathrm{K}\right): y=-0.0132 x+0.6214 \ldots(5)$

Suhu $40^{\circ} \mathrm{C}\left(313^{\circ} \mathrm{K}\right): y=-0.0153 x+0.6281 \ldots(6)$

Suhu $45^{\circ} \mathrm{C}\left(318^{\circ} \mathrm{K}\right): y=-0.0159 x+0.5944 \ldots(7)$

Persamaan regresi linier tersebut akan menghasilkan nilai $\mathrm{k} / \mathrm{b} /$ slope yang merupakan laju reaksi penurunan kadar vitamin $\mathrm{C}$ pada setiap suhu penyimpanan. Nilai $k$ untuk penurunan kadar vitamin $\mathrm{C}$ tertinggi terjadi pada suhu $45{ }^{\circ} \mathrm{C}$ yaitu 0.0159 . Nilai $k$ penurunan kadar vitamin $\mathrm{C}$ pada suhu $40{ }^{\circ} \mathrm{C}$ sebesar 0.0153 serta pada suhu $35^{\circ} \mathrm{C}$ nilai $k$ sebesar 0.0132 . Nilai $k$ semakin besar seiring dengan suhu penyimpanan yang semakin tinggi. Hal ini diperkuat oleh pendapat Syarif dan Halid (1993) bahwa suhu merupakan faktor yang berpengaruh terhadap mutu pangan. Semakin tinggi suhu penyimpanan maka laju reaksi berbagai senyawa akan semakin cepat. Safaryani et al. (2007) menyatakan bahwa beberapa faktor seperti kontak udara, sinar, panas, enzim oksidator, alkali, besi $(\mathrm{Fe})$, dan katalis tembaga $(\mathrm{Cu})$ dapat mempercepat oksidasi vitamin C. Akan tetapi, oksidasi vitamin $C$ dapat terhambat dengan penyimpanan suhu rendah atau keadaan sangat asam (Rahmawati dan Bundjali, 2012; Khaleghi et al., 2016; Lena Herbig dan Renard, 2017; Tomas dan Jafari, 2018).

Konstanta penurunan kadar vitamin $C$ tersebut kemudian diterapkan pada persamaan Arrhenius, yaitu $\ln k=\ln k_{0-}$ (E/RT). Setiap nilai $\ln k$ dan $1 / \mathrm{T}$ (satuan suhu dalam Kelvin) pada tiap suhu penyimpanan diplotkan sebagai ordinat dan absis. Parameter Arrhenius perubahan kadar vitamin $C$ pada sirup jeruk, yaitu 1/T dan $\ln K$ dapat dilihat pada Tabel 6.
Hasil plot antara nilai $1 / \mathrm{T}$ dan $\ln k$ akan meghasilkan grafik hubungan antar penurunan kadar vitamin $C$ dengan persamaan reaksi regresi linier $y=-1828.3 x+$ 1.6259 dan koefisien determinasi $\left(\mathrm{R}^{2}\right)$ sebesar 0.9026 (Gambar 3b). Koefisien determinasi mendekati satu $\left(R^{2} 1\right)$ artinya korelasi (hubungan) antara suhu dan penurunan kadar vitamin C sebesar 0.9942 (sangat tinggi) yang artinya semakin tinggi suhu penyimpanan maka penurunan kadar vitamin $\mathrm{C}$ pada sirup jeruk semakin besar. Menurut Steskova et al. (2006) pada minuman kemasan yang mengandung vitamin $C$ akan mengalami penurunan kadar vitamin $C$, apabila disimpan pada suhu yang tinggi.

\section{Perubahan Total Padatan Terlarut (TPT)}

Total Padatan Terlarut (TPT) menunjukkan bahan yang terlarut dalam larutan yang dinyatakan dalam ${ }^{\circ}$ Brix. Pengaruh penyimpanan terhadap TPT dapat diketahui dari persamaan regresi linier dengan pemilihan orde reaksi. orde reaksi yang digunakan untuk perubahan TPT adalah orde nol yang memiliki nilai $\mathrm{R}^{2}$ lebih besar dari orde satu. Orde reaksi yang digunakan adalah orde reaksi yang memiliki nilai $\mathrm{R}^{2}$ yang lebih besar (Labuza dan Riboh, 2007). Plot data hasil perubahan total padatan terlarut (TPT) selama penyimpanan pada tiga kondisi suhu yang berbeda dapat dilihat pada Gambar 2c.

Berdasarkan Gambar 2c dapat diketahui bahwa terjadi peningkatan TPT pada sirup jeruk sebanding dengan lama penyimpanan. Peningkatan TPT diduga dikarenakan oleh peningkatan kadar gula pereduksi dalam sirup jeruk. Menurut Yusuf (2002) sebagai besar perubahan total padatan terlarut pada minuman ringan adalah gula. Peningkatan kadar gula pereduksi tersebut diduga meningkatkan total padatan terlarut dalam sirup jeruk.

Berdasarkan hasil perhitungan dapat diketahui persamaan regresi linier antara Total Padatan Terlarut (TPT) dengan waktu penyimpanan, sesuai dengan Persamaan 8, 9, 10.

Suhu $35^{\circ} \mathrm{C}(308 \mathrm{~K}): y=0.1697 x+53.563 \ldots(8)$

Suhu $40{ }^{\circ} \mathrm{C}(313 \mathrm{~K}): y=0.1606 x+53.393 \ldots(9)$

Suhu $45^{\circ} \mathrm{C}(318 \mathrm{~K}): y=0.1926 x+53.085 \ldots(10)$

Persamaan regresi linier tersebut akan menghasilkan $\mathrm{k} / \mathrm{b} /$ slope yang merupakan laju reaksi dari peningkatan TPT. Nilai $k$ untuk peningkatan TPT tertinggi terjadi pada 
suhu $45^{\circ} \mathrm{C}$ yaitu 0.1926 . Nilai $k$ pada suhu 40 ${ }^{\circ} \mathrm{C}$ sebesar 0.1606 serta pada suhu $35^{\circ} \mathrm{C}$ nilai $k$ sebesar 0.1697. Terjadi penurunan laju reaksi pada suhu $40{ }^{\circ} \mathrm{C}$, diduga pada saat penyimpanan terjadi persebaran suhu yang tidak merata sehingga menghasilkan nilai yang kurang sesuai dengan dugaan. Berdasarkan persamaan dapat diketahui bahwa semakin tinggi suhu penyimpanan maka laju reaksi (k) semakin besar.

Konstanta peningkatan total padatan terlarut (TPT) kemudian diterapkan pada persamaan Arrhenius, yaitu $\ln k=\ln k_{0-}(E /$ $R T$ ). Setiap nilai $\ln k$ dan $1 / \mathrm{T}$ (satuan suhu dalam Kelvin) pada masing-masing suhu penyimpanan diplotkan sebagai ordinat dan absis. Parameter Arrhenius perubahan total padatan terlarut (TPT) pada sirup jeruk, yaitu $1 / \mathrm{T}$ dan $\ln K$ dapat dilihat pada Tabel 7.

Plot antara nilai $1 / \mathrm{T}$ dan $\ln k$ akan menghasilkan grafik hubungan antar peningkatan total padatan terlarut (TPT) dan suhu penyimpanan dengan persamaan reaksi regresi linier $\mathrm{y}=-1227.4 \mathrm{x}+2.172$ dengan koefisien determinasi $\left(R^{2}\right)$ sebesar 0.4524 (Gambar 3c). Jika nilai $\mathrm{R}^{2}=0$ maka $X$ dan $Y$ tidak memiliki relasi (hubungan) linier (Papadatos, 2014; Hanley, 2016). Koefisien determinasi mendekati nol $\left(R^{2} \sim 0\right)$ artinya hubungan antara suhu dan total padatan terlarut (TPT) sebesar 0.4524 (sangat rendah) yang artinya kenaikan suhu tidak mempengaruhi total padatan terlarut. Persamaan regresi linier yang di dapat dari plot $\ln k$ dan $1 / \mathrm{T}$ yaitu $y=-1227.4 x+2.172 ; \mathrm{E} / \mathrm{R}=1227.4$; dan ln $k_{0}: 2.172$. Berdasarkan persamaan tersebut maka dapat dihitung energi aktivasi (EA) dari parameter total padatan terlarut sebesar $2437.616 \mathrm{kal} / \mathrm{mol}$.

\section{Perubahan Derajat Keasaman (pH)}

Pengaruh penyimpanan terhadap perubahan nilai derajar keasaman $(\mathrm{pH})$ dapat diketahui dengan membuat persamaan regresi linier dengan pemilihan orde reaksi. Orde reaksi yang digunakan adalah orde reaksi yang memiliki nilai $\mathrm{R}^{2}$ yang besar (Labuza dan Riboh, 2007). Orde yang digunakan adalah orde satu yang memiliki nilai $\mathrm{R}^{2}$ lebih besar dari pada orde nol. Orde satu lebih besar dari pada nilai $\mathrm{R}^{2}$ pada orde nol di setiap suhu penyimpanan. Plot hasil perubahan nilai derajat keasaman $(\mathrm{pH})$ dapat dilihat pada Gambar 2d.

Berdasarkan Gambar 2d dapat diketahui bahwa terjadi penurunan nilai derajat keasaman $(\mathrm{pH})$ pada sirup jeruk yang sebanding dengan lama penyimpanan. Penurunan nilai derajat keasaman $(\mathrm{pH})$ menunjukkan bahwa sirup jeruk menjadi bersifat asam selama penyimpanan sehingga kualitas sirup jeruk menurun. Penurunan $\mathrm{pH}$ yang terjadi pada sirup jeruk disebabkan oleh adanya lanjutan kerusakan fermentatif. Pada proses fermentasi selain menghasilkan alkohol (etanol), juga menghasilkan $\mathrm{CO}_{2}$ dan asam-asam organik sehingga produk menjadi lebih masam yang ditunjukkan dengan adanya penurunan $\mathrm{pH}$ (Fardiaz, 1997; Alonso-Moreno dan García-Yuste, 2016; Rodrigues et al., 2018). Perubahan kondisi sirup jeruk menjadi masam dikarenakan terjadinya reaksi inversi sukrosa menjadi gula reduksi dan adanya aktivitas mikroorganisme. Kerusakan lebih lanjut dari degradasi sukrosa adalah terbentuknya asam-asam organik seperti asam laknat dan asam asetat (Kirca dan Cemeroğlu, 2003; Siriwattanayotin et al., 2006).

Berdasarkan hasil perhitungan dapat diketahui persamaan regresi linier antara nilai derajat keasaman $(\mathrm{pH})$ dengan waktu penyimpanan, sesuai dengan Persamaan 11, 12, 13.

Suhu $35^{\circ} \mathrm{C}(308 \mathrm{~K}): y=-0.0288 x+1.8697 . .(11)$

Suhu $40^{\circ} \mathrm{C}(313 \mathrm{~K}): y=-0.0290 x+1.8564 . .(12)$

Suhu $45^{\circ} \mathrm{C}(318 \mathrm{~K}): y=-0.0295 x+1.8133 \ldots(13)$

Persamaan 11, 12, 13, akan menghasilkan nilai $\mathrm{k} / \mathrm{b} /$ slope yang merupakan laju reaksi penurunan $\mathrm{pH}$ pada setiap suhu penyimpanan. Nilai $k$ untuk penurunan nilai $\mathrm{pH}$ tertinggi terjadi pada suhu $45^{\circ} \mathrm{C}$ yaitu 0.0295 . Nilai $k$ penurunan nilai $\mathrm{pH}$ pada suhu $40^{\circ} \mathrm{C}$ sebesar 0.0292 serta pada suhu $35{ }^{\circ} \mathrm{C}$ nilai $k$ sebesar 0.0288 . Nilai $k$ semakin besar seiring dengan suhu penyimpanan yang semakin tinggi. Hal ini diperkuat oleh pendapat Syarif dan Halid (1993) bahwa suhu merupakan faktor yang berpengaruh terhadap mutu pangan. Semakin tinggi suhu penyimpanan maka laju reaksi berbagai senyawa akan semakin cepat.

Konstanta penurunan nilai $\mathrm{pH}$ tersebut kemudian diterapkan pada persamaan Arrhenius, yaitu $\ln k=\ln k_{0-}(E / R T)$. Setiap nilai $\ln k$ dan $1 / \mathrm{T}$ (satuan suhu dalam Kelvin) pada masing-masing suhu penyimpanan diplotkan sebagai ordinat dan absis. Parameter Arrhenius perubahan nilai $\mathrm{pH}$ pada sirup jeruk, yaitu 1/T dan $\ln K$ dapat dilihat pada Tabel 8. 
Jurnal Teknologi Pertanian Vol. 19 No. 2 [Agustus 2018] 125-138

Analisis Kualitas Sirup Jeruk Baby Java [Yulidar dkk]

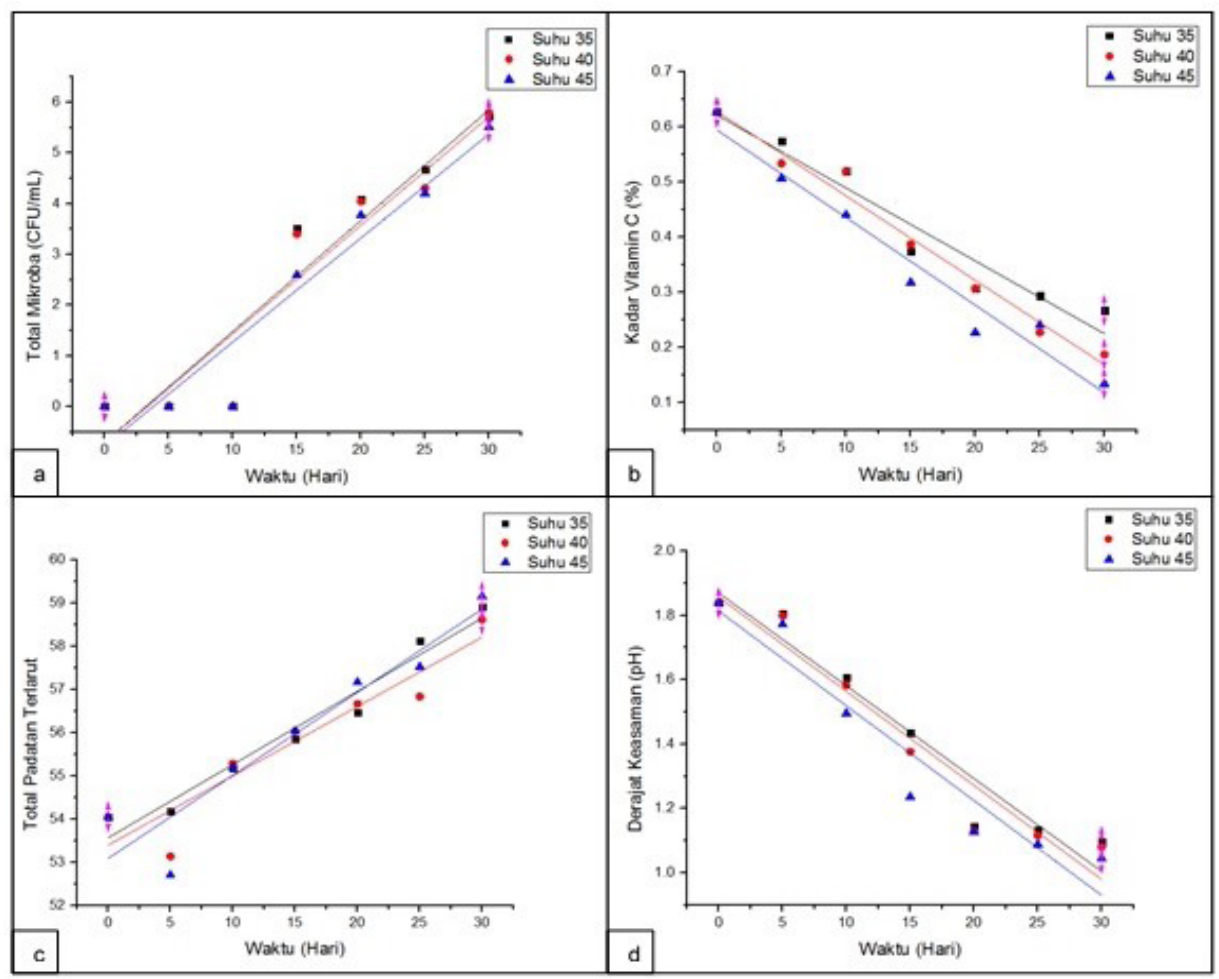

Gambar 2. Perubahan mutu tiap parameter pengamatan selama penyimpanan

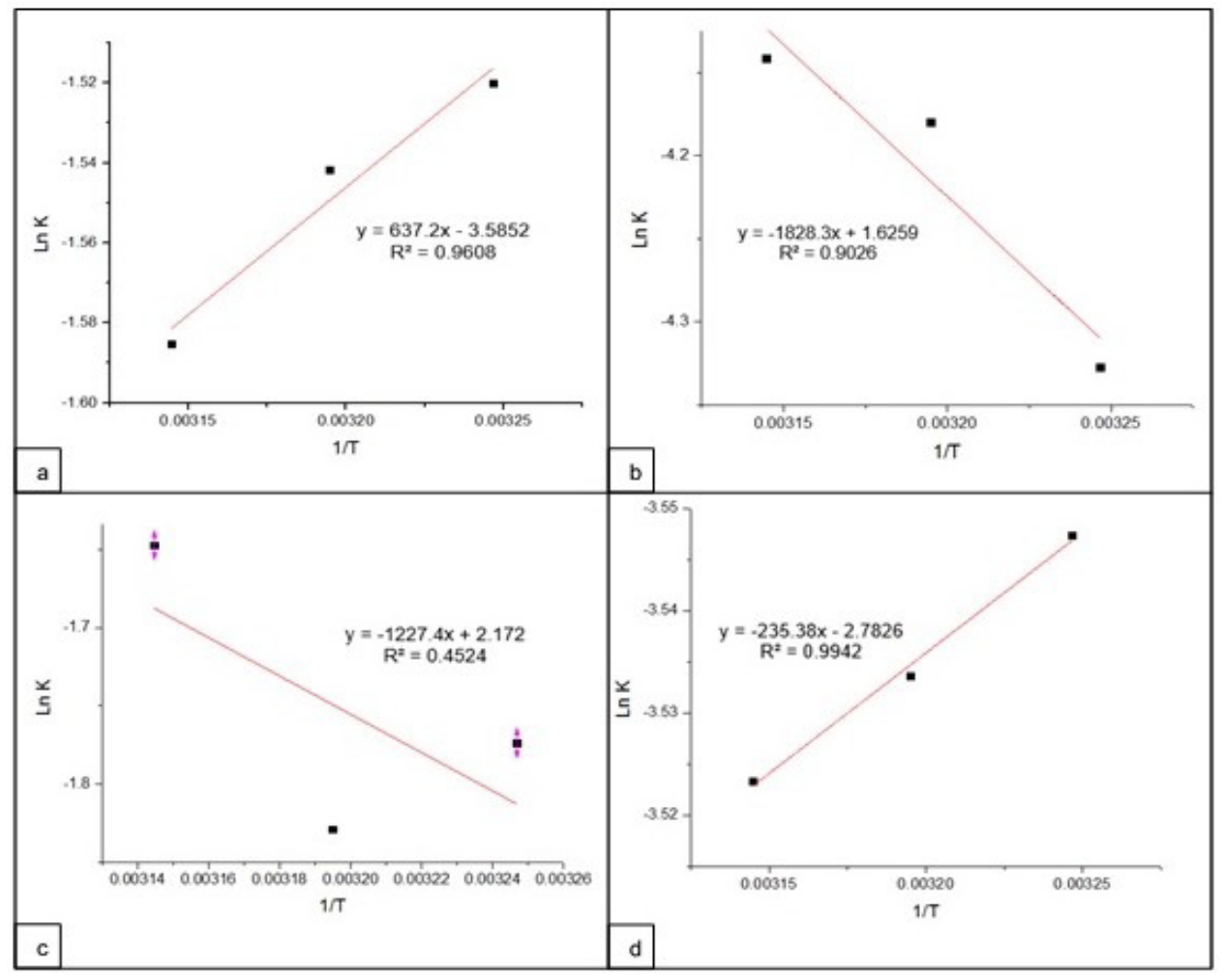

Gambar 3. Hubungan antara 1/T dan Ln k tiap parameter pengamatan 
Plot antara nilai $1 / \mathrm{T}$ dan $\ln k$ akan menghasilkan grafik hubungan penurunan nilai $\mathrm{pH}$ dan suhu penyimpanan dengan persamaan reaksi regresi linier $y=-235.38 x$ - 2.7826 dengan koefisien determinasi $\left(R^{2}\right)$ sebesar 0.9942 (Gambar 3d). Jika nilai $\mathrm{R}^{2}$ mendekati +1 atau $\mathrm{R}^{2}$ mendekati -1 maka $X$ dan $Y$ memiliki korelasi linier yang tinggi. Koefisien determinasi mendekati satu $\left(\mathrm{R}^{2} \sim 1\right)$ artinya hubungan antara suhu dan $\mathrm{pH}$ sebesar 0.9942 (sangat tinggi) yang artinya semakin tinggi suhu penyimpanan maka penurunan nilai $\mathrm{pH}$ sirup jeruk semakin besar.

Persamaan regresi linier yang di dapat dari plot $\ln k$ dan $1 / \mathrm{T}$ yaitu $y=-235.38 x$ - 2.7826; $\mathrm{E} / \mathrm{R}=235.38$ dan $\ln$ ko: 2.7826.Berdasarkan persamaan tersebut maka dapat dihitung energi aktivasi (EA) dari parameter nilai $\mathrm{pH}$ sebesar $467.46468 \mathrm{kal} / \mathrm{mol}^{\circ} \mathrm{K}$. Energi aktivasi tersebut memiliki arti bahwa besarnya energi minimal yang dibutuhkan molekul dalam sirup jeruk untuk menurunkan nilai $\mathrm{pH}$ adalah sebesar $467.46468 \mathrm{kal} /$ mol.

\section{Pendugaan Umur Simpan Sirup Jeruk}

Metode yang digunakan dalam pendugaan umur simpan sirup jeruk dalam penelitian ini adalah Accelerated Shelf Life Testing (ASLT). Menurut Robertson (1993) menyatakan bahwa ASLT merupakan metode yang dapat digunakan untuk memprediksi umur simpan suatu produk, dimana penelitian dilakukan dalam kondisi lingkungan yang dipercepat. Pendugaan umur simpan pada penelitian ini diasumsikan bahwa penurunan mutu paling dominan dipengaruhi suhu penyimpanan.

Penentuan masa simpan sirup jeruk dapat ditentukan berdasarkan laju reaksi penurunan mutu saat dilakukan penyimpanan dengan perlakuan suhu yang berbeda. Langkah selanjutnya dapat ditentukan energi aktivasi kerusakan bahan. Energi aktivasi ditentukan menggunakan persamaan Arrhenius, yang ditunjukkan pada Persamaan 14.

$\ln k=\ln k_{0}-\left(\mathrm{E}_{\mathrm{A}} / \mathrm{R}\right)(1 / \mathrm{T})$

dengan $\left(E_{A} / R\right)=$ slope $($ persamaan hasil plot Arrhenius $\ln A$ vs $1 / T$ ) Parameter yang digunakan untuk menentukan umur simpan sirup jeruk yaitu angka lempeng total mikroba (TPC), kadar vitamin $\mathrm{C}$, total padatan terlarut ( ${ }^{\circ}$ Brix), dan derajat keasaman $(\mathrm{pH})$. Pemilihan parameter untuk penentuan masa simpan sirup jeruk dengan mentukan nilai EA (energi aktivasi). Energi aktivasi merupakan energi yang diperlukan untuk mengaktivasi proses kerusakan (Labuza dan Riboh, 2007). Perhitungan $E_{A}$ tiap parameter dapat dilihat pada Tabel 9.

Berdasarkan Tabel 9, dapat diketahui bahwa parameter derajat keasaman $(\mathrm{pH})$ memiliki energi aktivasi paling kecil yaitu 467.46. Oleh karena itu, parameter derajat keasaman $(\mathrm{pH})$ dijadikan sebagai parameter kunci pendugaan masa simpan sirup jeruk. Parameter kunci yang telah ditentukan digunakan sebagai dasar penentuan masa simpan (t) yang dihitung menggunakan persamaan kinetika reaksi berdasarkan ordo reaksi parameter tersebut. Adapun nilai suhu digunakan dikonversi terlebih dahulu ke dalam suhu Kelvin $\left({ }^{\circ} \mathrm{K}\right)$, sehingga suhu $25^{\circ} \mathrm{C}$ menjadi $298^{\circ} \mathrm{K}$. Terlebih dahulu nilai laju reaksi $(k)$ dihitung dengan substitusi persamaan regresi linier $\ln k$ dan $1 / \mathrm{T}$ parameter $\mathrm{pH}$ terhadap persamaan Arrhenius seperti Persamaan 14. Ordo reaksi parameter $\mathrm{pH}$ mengikuti ordo satu, sehingga pendugaan masa simpan sirup jeruk menggunakan Persamaan 15.

$\mathrm{t}=\left(\operatorname{Ln} \mathrm{A}_{0}-\operatorname{Ln} \mathrm{A}_{\mathrm{t}}\right) / k$

dengan $\triangle \mathrm{A}$ merupakan selisih nilai mutu awal penyimpanan $\left(A_{0}\right)$ sebesar 6.29 dan akhir penyimpanan $\left(\mathrm{A}_{\mathrm{t}}\right)$ sebesar $2.01, \ln$ merupakan logaritma natural atau logaritma dengan bilangan pokok $e$, nilai $k$ adalah laju reaksi penurunan mutu yang didapatkan dari perhitungan. Hasil pendugaan masa simpan sirup jeruk dapat dilihat pada Tabel 10.

Berdasarkan Tabel 10 dapat diketahui bahwa pendugaan masa simpan sirup jeruk berbeda pada masing-masing suhu penyimpanan. Pada suhu refrigerator $\left(7^{\circ} \mathrm{C}\right)$ didapat masa simpan 42 hari, suhu ruang $\left(25^{\circ} \mathrm{C}\right)$ didapat masa simpan 40 hari, dan pada suhu tinggi $\left(35^{\circ} \mathrm{C}\right)$ didapat umur simpan 39 hari. Masa simpan yang relatif pendek, yaitu 40 hari apabila disimpan pada suhu $25^{\circ} \mathrm{C}$.

Parameter $\mathrm{pH}$ merupakan parameter yang paling dominan dapat diamati dari perubahan mutu sirup jeruk. Nilai $\mathrm{pH}$ dapat mempengaruhi perubahan mutu organoleptik sirup, khususnya rasa. Hal tersebut dapat diketahui dari hasil pengujian organoleptik yang menyimpulkan bahwa parameter rasa paling mempengaruhi penerimaan konsumen terhadap produk. Semakin kecil energi aktivasi $\mathrm{pH}$, maka perubahan nilai $\mathrm{pH}$ 
akan semakin cepat sehingga paling dominan mempengaruhi parameter rasa produk. Selain itu, nilai $\mathrm{pH}$ dapat mempengaruhi pertumbuhan mikroba dan secara tidak langsung berpengaruh pada daya awet bahan pangan. Saat dilakukan penyimpanan, mikroorganisme yang tersisa pada bahan akan aktif melakukan proses fermentasi. Menurut Fardiaz (1997), dalam proses proses fermentasi, mikroorganisme terutama khamir menghasilkan alkohol (etanol), gas $\mathrm{CO}_{2}$ dan asam-asam organik sehingga nilai $\mathrm{pH}$ akan semakin menurun. Kandungan mikroba khususnya khamir tersebut diduga karena adanya sel spora khamir yang bertahan walaupun telah dilakukan proses produksi. Kebanyakan mikroorganisme tahan terhadap suhu sedang sampai suhu sterilisasi dan walaupun sel mikroba mati, sel spora dapat tahan hidup untuk jangka waktu cukup lama dan akan aktif pada kondisi yang sesuai (Buckle, 1985; Deák, 2014; Li, X, Farid Serment-Moreno dan Welti-Chanes, 2016; Zhu et al., 2018).

Pertumbuhan kapang dan khamir pada sirup buah selama penyimpanan tidak diharapkan karena dapat merusak nutrisi yang terdapat pada sirup, sehingga sirup tidak layak dikonsumsi oleh konsumen. Kapang dapat hidup pada produk yang berkadar gula dan asam yang tinggi seperti sirup dengan merombak gula menjadi asam-asam organik yang dapat digunakan sebagai sumber energi bagi pertumbuhan kapang. Menurut Buckle (1985), bahan yang berkadar gula tinggi dan $\mathrm{pH}$ yang rendah merupakan media yang baik bagi pertumbuhan khamir dan kapang.

\section{SIMPULAN}

Berdasarkan hasil penelitian yang telah dilakukan, maka dapat disimpulkan bahwa proses produksi sirup jeruk baby java pada penelitian ini dapat secara efektif menurunkan cemaran mikroorganisme pada produk akhir. Hasil pengamatan menunjukkan pada tahap proses pertama yaitu persiapan bahan baku kandungan cemaran mikroba sebesar $9.86 \times 10^{2} \mathrm{CFU} / \mathrm{ml}$, kemudian hingga akhir tahap proses produksi yaitu pengemasan sirup tidak terdeteksi adanya kandungan mikroba. Hasil perhitungan menunjukkan bahwa derajat keasaman $(\mathrm{pH})$ pada penelitian ini merupakan parameter kunci untuk menduga masa simpan sirup jeruk baby java. Persamaan regresi yang didapatkan yaitu $y$ $=-235.38 x-2.7826$ dengan perhitungan energi aktivasi didapatkan sebesar $467.46 \mathrm{kal} /$ mol ${ }^{\circ} \mathrm{K}$. Pendugaan masa simpan didapatkan sirup jeruk baby java dapat disimpan selama 42 apabila disimpan pada suhu refrigerator (7 $\left.{ }^{\circ} \mathrm{C}\right)$, sedangkan apabila disimpan pada suhu ruang $\left(25^{\circ} \mathrm{C}\right)$ sirup jeruk dapat disimpan selama 40 hari dan apabila pada suhu tinggi (35 $\left.{ }^{\circ} \mathrm{C}\right)$ sirup jeruk dapat disimpan selama 39 hari.

\section{DAFTAR PUSTAKA}

Alonso-Moreno, C, García-Yuste, S. 2016. Environmental potential of the use of $\mathrm{CO}_{2}$ from alcoholic fermentation processes. The $\mathrm{CO}_{2}$-AFP strategy. Science of The Total Environment. 568:319-326

Andrzejewski, B, Eggleston, G, Powell, R. 2013. Pilot plant clarification of sweet sorghum juice and evaporation of raw and clarified juices. Industrial Crops and Products. 49:648-658

BPOM. 2012. Pedoman kriteria cemaran pada pangan siap saji dan pangan industri rumah tangga. Dilihat 20 April 2018. <http://standarpangan.pom.go.id/ dokumen/pedoman/Buku_Pedoman_ PJAS_tentang_Cemaran.pdf $>$

BPOM. 2016. Kriteria mikrobiologi dalam pangan olahan. Dilihat 20 April 2018. <http://standarpangan.pom.go.id/ dokumen/peraturan/2016/PerKa BPOM_No_16_Tahun_2016_tentang_ Kriteria_Mikrobiologi_dalam_Pangan_Olahan.pdf>

Buckle, KA. 1985. Ilmu Pangan. Universitas Indonesia Press, Jakarta

Dagnas, S, Onno, B, Membré, J, M. 2014. Modeling growth of three bakery product spoilage molds as a function of water activity, temperature and $\mathrm{pH}$. International Journal of Food Microbiology. 186:95-104

Dahlquist-Willard, R, M, Marshall, M, N, Betts, S, L, Tuell-Todd, C, C, Vandergheynst, J, S, Stapleton, J, J. 2016. Development and validation of a Weibull-Arrhenius model to predict thermal inactivation of black mustard (Brassica nigra) seeds under fluctuating temperature regimens. Biosystems Engineering. 151:350-360 
da Silva, M, F, Dionísio, A, P, Carioca, A, A, F, Adriano, L, S, Pinto, C, O, Abreu, F, A, P, Wurlit, N, J, Araújo, I, M, Garruti, D, S, Pontes, D, F. 2017. Yacon syrup: Food applications and impact on satiety in healthy volunteers. Food Research International. 100:460-467

Deák, T. 2014. Food Technologies: Sterilization. Encyclopedia of Food Safety. 3:245-252

Dewi, AK. 2016. Studi Pembuatan Sirup Jeruk Baby Java Subgrade (Kajian Konsentrasi Gula dan Konsentrasi Asam Sitrat). Skripsi. UB. Malang

Fardiaz, S. 1997. Analisis Mikrobiologi Pangan. Raja Grafindo Persada, Jakarta

Fish, W, W. 2012. A reliable methodology for quantitative extraction of fruit and vegetable physiological amino acids and their subsequent analysis with commonly available HPLC systems. Food and Nutrition Sciences. 3:863-871

Hanley, J, A. 2016. Simple and multiple linear regression: sample size considerations. Journal of Clinical Epidemiology. 79:112-119

Jafarpour, M, Yousefi, G, Hamedi, A, Shariat, A, Salehi, A, Heydari, M. 2016. Effect of a traditional syrup from Citrus medica L. fruit juice on migraine headache: a randomized double blind placebo controlled clinical trial. Journal of Ethnopharmacology. 179:170-176

Kebede, B, T, Grauwet, T, Magpusao, J, Palmers, S, Michiels, C, Hendrickx, M, Loey, A, V. 2015. An integrated fingerprinting and kinetic approach to accelerated shelf-life testing of chemical changes in thermally treated carrot puree. Food Chemistry. 179:94-102

Khaleghi, F, Arab, Z, Gupta, V, K, Ganjali, M, R, Norouzi, P, Atar, N, Yola, M, L. 2016. Fabrication of novel electrochemical sensor for determination of vitamin C in the presence of vitamin B9 in food and pharmaceutical samples. Journal of Molecular Liquids. 221:666-672

Kirca, A, Cemeroğlu, B. 2003. Degradation kinetics of anthocyanins in blood orange juice and concentrate. Food Chemistry. 81(4):583-587

Kumar Y, Krishna K, P, Vivek K. 2015. Pulsed electric field processing in food technology. International Journal of Engineering Studies and Technical Approach. 1(2):6-17

Kwan, T, H, Ong, K, L, Haque, M, A, Tang, W, Kulkarni, S, Lin, C, S, K. 2018. High fructose syrup production from mixed food and beverage waste hydrolysate at laboratory and pilot scales. Food and Bioproducts Processing. 111:141-152

Labuza, T, P, Riboh, D. 1982. Theory and application of arrhenius kinetic to prediction of nutrient losses in Food $3^{\text {th }}$ ed. Food Technology. 36:66-74

Lawless, HT, Heymann, H. 1998. Sensory Evaluation of Food: Principles and Practices. Chapman \& Hall, New York

Lena Herbig, A, Renard, C, M, G, C. 2017. Factors that impact the stability of vitamin $\mathrm{C}$ at intermediate temperatures in a food matrix. Food Chemistry. 220:444-451

Li, X, Farid, M. 2016. A review on recent development in non-conventional food sterilization technologies. Journal of Food Engineering. 182:33-45

Liu, X, Jiang, Y, Shen, S, Luo, Y, Gao, L. 2015. Comparison of Arrhenius model and artificial neuronal network for the quality prediction of rainbow trout (Oncorhynchus mykiss) fillets during storage at different temperatures. LWT - Food Science and Technology. 60(1):142-147

Luethy, P, M, Zelazny, A, M.2018. Rapid onestep extraction method for the identification of molds using MALDI-TOF MS. Diagnostic Microbiology and Infectious Disease. 91(2):130-135

Margono, T, Suryati, D, Hartinah, S, Somadikarta, L. 2000. Panduan Teknologi Pangan. Pusat Informasi Wanita dalam Pembangunan PDII-LIPI, Jakarta

Marta, H, Widyasanti, A, Sukarti, T. 2008. Pengaruh penggunaan jenis gula dan konsentrasi sari buah terhadap beberapa karakteristik sirup jeruk keprok garut (Citrus nobilis L.). Jurnal Teknotan. 2(1)

McCurdy, S, Joey, P, Grace, W. 2018. Storing food for safety and quality. Dilihat 20 April 2018. < https://www. researchgate.net/profile/ Beemnet_ Kassahun/post/How_to_improve_ the_conservation_of_fresh_foods / attachment/5ac591b9b53 $\mathrm{d} 2 \mathrm{f} 63 \mathrm{c} 3$ c3f1db/AS\%3A611889935568896 $\% 401522897337117$ / download / Frsh+food+longer+storage1.pdf>

Muchtadi, TR. 2010. Teknologi Proses Pengolahan Pangan. AlfaBeta, Bandung

Mukaromah, U, Susetyorini, S, H, Aminah, S. 2010. Kadar vitamin C, mutu fisik, pH, dan mutu organoleptik sirup rosella 
(Hibiscus sabdariffa L.) berdasarkan cara ekstraksi. Jurnal Pangan dan Gizi. 1(1):43-51

Nordstrom, D, K, Alpers, C, N, Ptacek, C, J, Blowes, D, W. 2000. Negative $\mathrm{pH}$ and extremely acidic mine waters from iron mountain, california. Environ. Sci. Technol. 34:254-258

Olorunjuwon O, B, Temitope, K, Muibat O, F, Afolabi, O. 2014. Microbiological quality of some locally-produced fruit juices in ogun state, south western nigeria. E3 Journal of Microbiology Research. 2(1):1-8

Palluzi, R. 2009. Pilot Plants: Destined for Development. Putman Media, USA

Papadatos, N. 2014. Some counterexamples concerning maximal correlation and linear regression. Journal of Multivariate Analysis. 126:114-117

Park, H, R, Kim, K, Lee, S, J. 2013. Adjustment of Arrhenius activation energy of laccase-based time-temperature integrator (TTI) using sodium azide. Food Control. 32(2):615-620

Pato, U, Restuhadi, F, Ali, A, Ulfah, R, Mukmin. 2012. Evaluasi mutu dan daya simpan roti manis yang dibuat melalui substitusi tepung terigu dengan pati sagu dan mocaf. Agricultural Science and Technology Journal. 11(1):1-12

Rahmawati, S, Bundjali, B. 2012. Kinetics of the oxidation of vitamin C. Indo. I. Chem. 12(3):291-296

Ramaswamy, H, Marcotte, M. 2005. Food Processing Principles and Applications. Taylor \& Francis, New York

Rienoviar, Nashrianto, H. 2010. Penggunaan asam askorbat (vitamin C) untuk meningkatkan daya simpan sirup rosela (Hibiscus sabdariffa Linn.). Jurnal Hasil Penelitian Industri. 23(1):8-18

Rico-Munoz, E, Samson, R, A, Houbraken, J. 2018. Mould spoilage of foods and beverages: using the right methodology. Food Microbiology.

Robertson, GL. 1993. Food Packaging Principles and Practices. Marcell Dekker Inc, New York

Rodrigues, K, C, S, Sonego, J, L, S, Cruz, A, J, G, Bernardo, A, Badino, A, C. 2018. Modeling and simulation of continuous extractive fermentation with $\mathrm{CO} 2$ stripping for bioethanol production. Chemical Engineering Research and Design. 132:77-88

Safaryani, N, Haryanti, S, Hastuti, E, D. 2007. Pengaruh suhu dan lama penyimpanan terhadap penurunan kadar vitamin C brokoli (Brassica oleracea
L.). Buletin Anatomi dan Fisiologi. 15(2):39-45

Satuhu, S. 2004. Penanganan dan Pengolahan Buah. Penebar Swadaya, Jakarta

Serment-Moreno, V, Welti-Chanes, J. 2016. Sterilization of Foods. Encyclopedia of Food and Health. 175-180

Siriwattanayotin, S, Yoovidhya,T, Meepadung, T, Ruenglertpanyakul, W. 2006. Simulation of sterilization of canned liquid food using sucrose degradation as an indicator. Journal of Food Engineering. 73(4):307-312

Steele, R. 2004. Understanding and Measuring the Shelf Life of Food. Woodhead Publishing Limited, England

Steskova, A, Morochovičové, M, Lešková, E. 2006. Vitamin C degradation during storage of fortified foods. Journal of Food and Nutrition Research. 45(2):55-61

Syarif, R, Halid, H. 1993. Teknologi Penyimpanan Pangan. Pusat Antar Universitas Gadjah Mada, Yogyakarta

Tomas, M, Jafari, S, M. 2018. Influence of food processing operations on vitamins. Reference Module in Food Science

Triharjono, A, Probowati, B, D, Fakhry, M. 2013. Evaluasi prosedur standar sanitasi kerupuk amplang di UD Sarina. AGROINTEK. 7(2):76-83

Upasen, S, Wattanachai, P. 2018. Packaging to prolong shelf life of preservativefree white bread. Heliyon. 4(9):e00802

Widya, A, S, Yuwono, S, S. 2014. Pendugaan umur simpan minuman berperisa apel menggunakan metode accelerated shelf life testing (ASLT) dengan pendekatan arrhenius. Jurnal Pangan dan Agroindustri. 2(3):203-213

Yusuf, RR. 2002. Formulasi, karakteristik kimia, dan uji aktivitas antioksidan produk minuman fungsional tradisional sari jahe (Zingiber officinale Rosc.) dan sari sereh dapur (Cymbopogon flexuosus). Skripsi. IPB. Bogor

Zakaria, WA, Prasmatiwi, FE, Abidin, Z, Murniati, K, Indriani, Y, Saleh, Y, Solimah, Marpaung, TH, Sutarsono, Buana, WP. 2013. Efisiensi Sistem Produksi dan Tataniaga Hortikultura. Badan Pusat Statistik, Jakarta

Zhu, Z, Cai, H, Sun, D, W. 2018. Titanium dioxide (TiO2) photocatalysis technology for nonthermal inactivation of microorganisms in foods. Trends in Food Science \& Technology. 75:23-35 